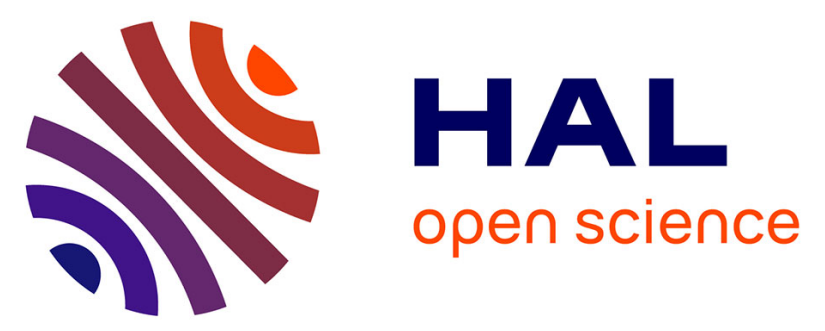

\title{
Identifying obstacles and ranking common biological control research priorities for Europe to manage most economically important pests in arable, vegetable and perennial crops
}

Jay Ram Lamichhane, Monika Bischoff-Schaefer, Sylvia Bluemel, Silke Dachbrodt-Saaydeh, Laure Dreux, Jean-Pierre Jansen, József Kiss, Jürgen Köhl, Per Kudsk, Thibaut Malausa, et al.

\section{- To cite this version:}

Jay Ram Lamichhane, Monika Bischoff-Schaefer, Sylvia Bluemel, Silke Dachbrodt-Saaydeh, Laure Dreux, et al.. Identifying obstacles and ranking common biological control research priorities for Europe to manage most economically important pests in arable, vegetable and perennial crops. Pest Management Science, 2017, 73 (1), pp.14-21. 10.1002/ps.4423 . hal-02625012

\section{HAL Id: hal-02625012 \\ https://hal.inrae.fr/hal-02625012}

Submitted on 26 May 2020

HAL is a multi-disciplinary open access archive for the deposit and dissemination of scientific research documents, whether they are published or not. The documents may come from teaching and research institutions in France or abroad, or from public or private research centers.
L'archive ouverte pluridisciplinaire HAL, est destinée au dépôt et à la diffusion de documents scientifiques de niveau recherche, publiés ou non, émanant des établissements d'enseignement et de recherche français ou étrangers, des laboratoires publics ou privés. 


\section{Identifying obstacles and ranking common biological control research priorities for Europe to manage most economically important pests in arable, vegetable and perennial crops}

Jay Ram Lamichhane,a, b* Monika Bischoff-Schaefer,c Sylvia Bluemel, ${ }^{\text {, }}$ Silke DachbrodtSaaydeh,c Laure Dreux,a Jean-Pierre Jansen,e Jozsef Kiss, ${ }^{\mathrm{f}}$ Jürgen Köhl,g Per Kudsk, Thibaut Malausa, ${ }^{\mathrm{i}}$ Antoine Messéan, ${ }^{\mathrm{a}}$ Philippe C. Nicot, ${ }^{\mathrm{b}}$ Pierre Ricci, ${ }^{\mathrm{i}}{ }^{\mathrm{J}}$ érôme Thibiergej and François Villeneuve ${ }^{k}$

aEco-Innov Research Unit, INRA, 78850 Thiverval-Grignon, France

bPlant Pathology Research Unit, INRA, 84143 Montfavet, France

'Julius Kühn-Institut, Federal Research Centre for Cultivated Plants, Stahnsdorfer Damm 81, 14532 Kleinmachnow, Germany

dInstitute of Plant Health, Austrian Agency for Health and Food Safety (AGES), Vienna, Austria

eWalloon Agricultural Research Centre, Life Science Department, Chemin de Liroux, 2, 5030 Gembloux, Belgium

fPlant Protection Institute, Szent Istvan University, Pater K. Street 1, H-2100 Gödöllö, Hungary

gWageningen University \& Research centre, Biointeractions and Plant Health, Droevendaalsesteeg 1, 6700 AA Wageningen, The Netherlands

hAarhus University, Department of Agroecology, Forsoegsvej 1, 4200 Slagelse 14, Denmark

iINRA, Univ. Nice Sophia Antipolis, CNRS, UMR 1355-7254 Institut Sophia Agrobiotech, 06900 Sophia Antipolis, France

Invivo AGRINOVEX, Ferme du Corbeau, 91490 Milly-la-Forêt, France

kCtifl, Centre de Lanxade, 28, route des Nébouts, 24130 Prigonrieux, France

*Corresponding author E-mail: jayram.lamichhane@gmail.com

Tel: +33 (0)5 612850 83; Fax: +33 (0)561765537

This article has been accepted for publication and undergone full peer review but has not been through the copyediting, typesetting, pagination and proofreading process, which may lead to differences between this version and the Version of Record. Please cite this article as doi: $10.1002 / \mathrm{ps} .4423$ ce document 


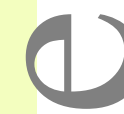
.
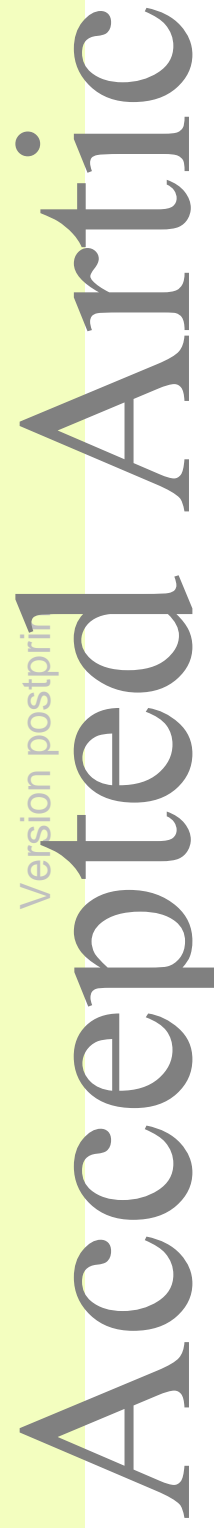

involved in the crop protection sector. These needs have led to specific interest in the learning and training processes with a focus on co-innovation dynamics involving a wide range of actors in the construction of innovations through strategic choices. Unlike the traditional crop protection model, where innovations were supplied as 'ready-to-use' tools, IPM is a dynamic system constantly modulated by end-users. To make any IPM system successful there is a need to put in place alternatives to conventional pesticides and plant protection measures that allow an effective management of crop pests (animal pests, pathogens and weeds). Biocontrol has the potential to become one of the main pillars of IPM systems and thus represents a key lever for a reduced reliance on conventional pesticides. Its principle is based on managing the balance of pest populations rather than eradicating them (pest management rather than pest control). In this paper, for biocontrol we refer to all methods/tools/measures/agents of plant protection which rely on the use of beneficial organisms ${ }^{2}$ as well as their natural mechanisms and interactions which govern the relationship between biological species in the natural environment. Thus, this includes augmentative control, conservation biocontrol, but also the use of biopesticides, semiochemicals and plant defense stimulators.

Recent developments in the regulation of pesticides at European level - notably Regulation $1107 / 2009 / \mathrm{EC}^{3}$ - have created favorable conditions for biocontrol R\&I in Europe. This legal requirement on the authorization and use of plant protection products have potential to promote biocontrol R\&I in Europe. In particular, the classification of active ingredients into four groups (basic, low-risk and standard substances, and candidates for substitution) would allow to place biocontrol agents within the low-risk category making their registration easier and less expensive. Also natural products of plant origin represent an important group of candidates to be included within the low-risk substances. ${ }^{4}$ The EU has recently approved a first list of low-risk substances (e.g. Isaria fumosorosea (syn. Paecilomyces fumosoroseus), Pepino mosaic virus). The need to have a fast approval process for low-risk substances and harmonization of the assessment procedure within the EU member states was recently discussed in an international stakeholder meeting. ${ }^{5}$ Data requirements for the approval of active substances and plant protection products needed at EU level are mainly adapted to conventional pesticides and there is not yet a different approval and registration procedure for biocontrol solutions ${ }^{6}$ nor there is any registration procedure 
for biostimulants. ${ }^{7}$ There are similar constraints while dealing with pesticide residue issues which are required to fulfil the European Regulation (EC) No. 1107/2009.8,9

Biocontrol R\&I has become increasingly dynamic and involves a wide range of stakeholders from a variety of public institutions and companies (cooperatives and private companies). However, biocontrol R\&I efforts are often carried out within national initiatives and in a fragmented fashion. Therefore, their operational outputs would benefit from closer collaboration between academia, the industry and the agricultural sectors, on one hand, and from transnational cooperation, on the other. In addition, a greater level of collaboration/knowledge-sharing is required to address key biocontrol needs and to pool biocontrol R\&I efforts nationally and internationally on common pest priorities for a better biocontrol service provision.

Taking into account the particularly favorable current environment to address biocontrol R\&I challenges in Europe, three networks concerned by biocontrol research organized a "Joint international workshop on biocontrol" in Paris, France on the $27^{\text {th }}$ and $28^{\text {th }}$ of January 2016. These networks are the French National Action Plan "Ecophyto"10, the European Research Area Network of Integrated Pest Management in Europe ${ }^{11}$, and the West Palearctic Regional Section of the International Organization for Biological and Integrated Control. ${ }^{12}$ Fifty-three experts from 16 countries - including scientists, governmental officials, policy makers, company representatives and agricultural advisors - met, discussed and ranked the most important and common pest problems in arable, vegetable (both indoor and outdoor), and perennial (orchards and vineyards) crops in Europe.

This paper aims to present the major outcomes of the workshop obtained by a questionnaire survey and a face-to-face group discussion. The questionnaire was designed and circulated in advance to all invited participants to receive their feedback on the most relevant biocontrol R\&I issues in Europe. Additional responses were also received from experts who did not attend the workshop. The questionnaire included seven queries with multiple-choice answers and also provided the possibility for the respondents to express alternative opinions (Tables 1; Supplementary material S1). The face-to-face group discussion was held during the workshop for each of the three crop groups mentioned above, and mainly focused on the sorting and ranking of the major pest problems and biological control priorities shared between European countries. 


\section{Statistics on the questionnaire survey on major biocontrol research and implementation bottlenecks}

Overall, 63 biocontrol experts from over 20 countries provided the completed questionnaire. The responses were analyzed and the figures are presented in Table 1.

None of the respondents considered biocontrol as an independent approach to IPM. Because the efficacy of biocontrol methods is often considered as too limited to be relied upon singly for pest control, most participants emphasized that integrating biocontrol into IPM strategies, through the combination of different methods with partial effects, is particularly relevant to reduce reliance on conventional pesticides.

The opinions were divided concerning factors hindering the development of biocontrol in Europe. While for almost one third of the respondents the main obstacle was the absence of a sufficiently large array of biocontrol solutions to enable the build-up of pest management strategies, others stated that the lack of projects aiming at integrating biocontrol solutions with other measures and limited funding for biocontrol research were the main impediments to biocontrol development. Some respondents provided other responses including insufficient communication between research organizations in Europe, leading to an overlap of activities, insufficient biocontrol research demand due to the availability of chemical pesticides, the lack of long-term funding schemes or the lack of multidisciplinary biocontrol research aiming at integrating biocontrol products to other measures (Supplementary material S1).

There was not a clear consensus on the potential factors hindering the implementation of biocontrol in Europe. The lack of commercially available bio-pesticides was the most frequent answer, followed by the lengthy and expensive registration process for biopesticides. Concerning the latter, the EU is supposed to come up with a proposal for a simplified dossier for the authorization of low-risk substances. Such a new scenario will result in a reduced legislative burden thereby favoring market availability of biocontrol solutions in Europe. Other responses included: the varying effectiveness of biocontrol products/agents due to very diverse and variable climatic conditions and site-specific factors across Europe, the reluctance of growers to take risks with methods whose performances are perceived as uncertain, difficulty to evaluate the performance and impact of biocontrol methods posing particular problems linked to their partial effects, 
variable efficacy of biocontrol tools/measures compared to chemical solutions and growers' expectations that biocontrol solutions should be as quick and effective as chemical pesticides, constraints linked to the organization of work and compatibility with other agronomic practices, lack of evidence showing successful strategies to integrate biocontrol into IPM, lack of knowledge on the unintentional effects of biocontrol products/agents, lack of methods to assess the benefits of biocontrol to human health and the environment, and lack of public incentives for farmers to use biocontrol (Supplementary material S1).

Opinions were equally split on whether biocontrol research in Europe should focus on the development of new biocontrol products, or on the optimization of their efficacy, with a majority advocating to consider both objectives altogether. Many additional suggestions concerned the demonstration of efficacy of biocontrol at field level and the integration of biocontrol with other strategies, including conservation biocontrol, in the context of cropping system management (Supplementary material S1).

There was almost a clear consensus among the respondents about the major factor(s) to be considered while implementing biocontrol measures. Most of them emphasized the need to focus on multiple interactions while only a few considered the interactions between biocontrol and plant genetics as more important. In addition, application techniques, formulation of the biocontrol products, instructions for growers or advisors were mentioned, as well as a number of socio-economic factors (a biocontrol program is in most of case more expensive than a chemical protection program) influencing the uptake of biocontrol: the effects of market dynamics (the positioning of biocontrol products among inputs, the positioning of agricultural products from practices using biocontrol) and the role of incentives (quality labels or certification, financial incentives) from industries and public policy (Supplementary material S1).

The majority of the respondents indicated that biocontrol should focus on multiple pest targets rather than single pest species, especially when a biocontrol program is composed of different biocontrol agents/products. Comments underlined the need to balance the practical benefits of biocontrol products having a broad range of actions with their risks in terms of unintentional effects to non-target organisms (Supplementary material S1). 
Finally, most of the respondents stated that strengthening the effectiveness of biocontrol by other agronomic practices/strategies and decision support systems can promote biocontrol, although a few of them mentioned that partial plant resistance is the best way to this aim. Adjustments to the ecosystem, precise knowledge of the pest densities and the actual status of the targeted stage of pests in the field to improve the timing of the application, the use of local biocontrol agents to get the best adaptation to the local conditions, recognition of the importance of biocontrol at farmers' level as well as on society level were other measures stated as factors enhancing biocontrol during its application (Supplementary material S1).

\section{Ranking of biological control research priorities}

During the individual discussion phase, the participants from each crop group were asked to provide the top-ten pest priorities to be tackled in their own country. While setting up such a priority list, participants were requested to take into account: i) the potential economic impact, in terms of yield loss and quality implications, associated with a given pest on a given crop, and ii) the possible lack of conventional chemical control solutions, due either to the withdrawal from the market of previously available pesticides or further restriction in their use. In some cases, the increased risk of resistance development to conventional pesticides were also taken into account. The overall objective was to identify all those economically important pests for which no or little sustainable pest management options, notably biocontrol solution, are available. The discussion was followed by a sorting phase, during which common pest problems for each crop type were grouped, based on the number of countries sharing the same problem/s followed by their ranking in order of importance.

\subsection{Arable crops}

Arable crops comprise a wide variety of crops, including cereals, oilseed rape, peas and beans, sugar beet and potatoes. Although a number of conventional pesticides are available to manage most economically important pests of arable crops, growers suffer from the lack of effective management solutions for certain pests. Therefore, growers require more tools and consequently there is a strong need to develop biocontrol solutions to protect these crops. 
A final list of 13 common priority pest problems that were sorted and ranked for arable crops is reported in Table 2. Overall, it has emerged that few biocontrol solutions are available on the market for growers to manage these pests. Although some new biocontrol solutions are under development, there is a need for enlarging research efforts, especially for the screening of new biocontrol agents for arable crops.

\subsection{Vegetable crops}

Many vegetable crops fall under the category of "minor or speciality crops" which acutely suffer from the lack of effective conventional pesticides. ${ }^{13}$ Vegetable crops in Europe are characterized by a large diversity of species (more than 60) with marked differences in terms of the cultivated hectares for each crop (from less than 100 ha to several thousands). Further, for each crop, there is an important diversity of production technics adopted to supply products to the market all year round. Even when conventional pesticides are available, market acceptability driven by residues in food products is an issue for a number of vegetables as they are consumed fresh. Finally, the resistance of several important pests to pesticides and the sensitivity of pollinators to these products (e.g. bumblebees) urge for an important adaptation of pest management methods. Therefore, biocontrol, along with other alternative measures to conventional pesticides, has an important role to play to protect this crop group. Another concern is that while biocontrol in vegetable crops is widely practiced in protected environments such as greenhouses ${ }^{14,15}$ its use under field conditions is still limited. This requires that biocontrol measures available and used in greenhouses are adapted to field conditions although it is not always feasible since interacting factors in outdoor conditions are different than those from indoor conditions.

Table 3 presents a list of 12 common pest problems which were sorted and ranked seeking an immediate need for biocontrol solutions. Unlike the case of arable crops, there are many ongoing efforts in the development of biocontrol solutions for major vegetable crops with a number of products already available on the market. Therefore, besides the need of developing new products, research should also address the issues of optimizing, integrating and implementing already available products/measures.

\subsection{Perennial crops}


The perennial crops considered covered grapevine and different fruit crops, most of which are "minor crops". Consequently, the requirement of biocontrol R\&I for this crop group is important for the same reason as described above. Although biocontrol is increasingly applied in perennial crops, ${ }^{16,17}$ there is still a number of important pest problems for which no biocontrol solution is available or even under development.

This is illustrated by Table 4 which lists 12 common pest problems on perennial crops urgently requiring biocontrol solutions. Consequently, a wide range of needed research actions is advocated, firstly in the screening of new agents, but also on, integration and adoption of the new biocontrol solutions.

\section{Conclusions and perspectives}

This survey highlights the considerable gap between the current offer in biocontrol solutions and what farmers would need to manage important pest problems. The primary demand addressed to R\&I is on enlarging the range of biocontrol solutions through screening for new biocontrol agents suitable for commercial use ${ }^{18}$ and engineering new methods.

Contributors to the survey have further identified diverse factors currently impeding the development of biocontrol and suggested research approaches to help raise these constraints. These suggestions can be summarized in the following recommendations: (1) invest in the appropriate assessment of biocontrol methods, including both the consideration of their potential unintentional effects and the identification of the contextual factors that determine their performance, in order to improve farmers' guidance on the proper use of biocontrol; (2) devise strategies combining biocontrol methods with other pest management tactics, in the context of IPM or even cropping system management, to help farmers integrate biocontrol into their practices; (3) enlarge the scope of biocontrol research to the socioeconomic factors influencing biocontrol adoption, which calls for the development of multidisciplinary projects involving diverse actors throughout the value chain of agriculture.

Compared to fruit or vegetables, arable crops are in a markedly different situation: a lower input/cost per hectare and a lower consumers' concern on pesticide residues reduce the incentive to introduce biocontrol. Additional efforts are needed to raise 
awareness on the positive environmental effects expected from biocontrol in arable crops because of their huge acreages. Conservation biocontrol could be an interesting approach in this context which might be fostered by recent EU agri-environmental funding schemes aiming at promoting farmland ${ }^{19}$.

These recommendations issued by a large panel of experts represent a valuable contribution to the definition of priorities in biocontrol research and attractive opportunities for transnational joint initiatives.

\section{Acknowledgements}

The authors thank the anonymous reviewers for providing a number of valuable comments on the earlier version of the paper and all participants of the workshop for their active and valuable contribution to the discussion as well as those who did not attend but provided feedback on the questionnaire. The ERA-Net C-IPM is funded by the EU under the $7^{\text {th }}$ framework programme (Grant agreement no: 618110).

\section{References}

1. Lamichhane JR, Dachbrodt-Saaydeh S, Kudsk P, Messéan A. Towards a reduced reliance on conventional pesticides in European agriculture. Plant Dis 100:10-24 (2016).

2. Eilenberg J, Hajek A, Lomer C. Suggestions for unifying the terminology in biological control. BioControl 46:387-400 (2001).

3. European Commission. Regulation (EC) No 1107/2009 of the European Parliamnt and of the Council of 21 October 2009 concerning the placing of plant protection products on the market and repealing Council Directives 79/117/EEC and 91/414/EEC (2009).

4. Villaverde JJ, Sandin-Espana P, Sevilla-Morán B, López-Goti C, Alonso-Prados JL. Biopesticides from natural products: Current development, legislative framework, and future needs. BioResources 11:5618-5640 (2016).

5. Customised approach to assess the efficacy of low-risk plant protection products. http://www.ctgb.nl/en/news/news-items?tags=42274b1e-9206-6d2d-95bc-ff0000fe3321 
(2016).

6. Villaverde JJ, Sevilla-Morán B, Sandín-España P, López-Goti C, Alonso-Prados JL. Biopesticides in the framework of the European Pesticide Regulation (EC) No. 1107/2009. Pest Manag Sci 70:2-5 (2014).

7. Matyjaszczyk E. Products containing microorganisms as a tool in integrated pest management and the rules of their market placement in the European Union. Pest Manag Sci 71:1201-1206 (2015).

8. Villaverde JJ, Sevilla-Morán B, López-Goti C, Alonso-Prados JL, Sandín-España P. Trends in analysis of pesticide residues to fulfil the European Regulation (EC) No. 1107/2009. Trends Anal Chem 80:568-580 (2016).

9. European Commission (EC) Guidance document SANCO/12571/2013 rev. 0 on analytical quality control and validation procedures for pesticide residues analysis in food and feed, pp. 1-48 (2013).

10. The French National Action Plan "Ecophyto". http://agriculture.gouv.fr/ecophytokesako-0.

11. The European Research Area Network on Integrated Pest Management. http://cipm.org/.

12. The West Palearctic Regional Section of the International Organization for Biological and Integrated Control. http://www.iobc-wprs.org.

13. Lamichhane JR, Arendse W, Dachbrodt-Saaydeh S, Kudsk K, Roman JC, van Bijsterveldt-Gels JEM, Wick M, Messéan A. Challanges and opportunities for integrated pest management in Europe: a telling example of minor uses. Crop Prot 74:42-7 (2015).

14 Bale JS, van Lenteren JC, Bigler F. Biological control and sustainable food production. Philos Trans R Soc Lond B Biol Sci 363:761-76 (2008).

15. Calvo JC. Biological control of insect and mite pests in greenhouse solanaceous crops. BioControl 2:125-44 (2008).

16. Gabarra R, Riudavets J, Rodríguez GA, Pujade-Villar J, Arnó J. Prospects for the biological control of Drosophila suzukii. BioControl 60:331-9 (2015). 
17. Cazorla FM, Mercado-Blanco J. Biological control of tree and woody plant diseases: an impossible task? BioControl DOI 10.1007/s10526-016 - 9737-0 (2016).

18. Köhl J, Postma J, Nicot P, Ruocco M, Blum B. Stepwise screening of microorganisms for commercial use in biological control of plant-pathogenic fungi and bacteria. BiolControl 57:1-12 (2011).

19. Holland JM, Bianchi FJJA, Entling MH, Moonen A-C, Smith BM, Jeanneret P. Structure, function and management of semi-natural habitats for conservation biological control: a review of European studies. Pest Manag. Sci doi:10.1002/ps.4318 (2016). 
Table 1. Relevant questions and multiple answers related to biocontrol RDI asked through the questionnaire. The same respondent could provide more than one answer to the same question. In total, Sixty-three experts responded to the questionnaire.

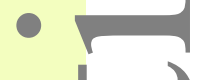

Question $\quad$ Multiple responses provided Percentage

1. What is your opinion on biocontrol as Biocontrol is an independent approach for crop protection 0

a crop protection measure?

78

Biocontrol is part of IPM

16

Other (specify)*

No response

2. What hinders the development of biocontrol measures in Europe?

Limited funding for biocontrol research (A)

10

Lack of projects aiming at integrating biocontrol products to other measures (B)

Insufficient range of biocontrol solutions to build up strategies ('C)

$\mathrm{A}+\mathrm{B}$

$\mathrm{B}+\mathrm{C}$

$\mathrm{C}+\mathrm{A}$

All of them

Other (specify)*

No response

3. What hinders the development and implementation of biocontrol in

Lengthy and expensive registration process for bio-pesticides (A)

Lack of commercially available bio-pesticides (B)

Low effectiveness of bio-pesticides due to very diverse climatic conditions ('C)

$\mathrm{A}+\mathrm{B}$

$\mathrm{B}+\mathrm{C}$

14

$\mathrm{C}+\mathrm{A}$

All of them

13

Other (specify)* 
4. What biocontrol research should focus on in Europe?

5. What is/are the main factor/s to be considered while implementing biocontrol measures?

6. What biocontrol solutions should focus on?

Which measure/s can enhance biocontrol during its application?
On the development of new biocontrol products

Both

Other (specify)*

No response

Tritrophic interactions (biocontrol agent/tool. biotic and abiotic factors)

The interactions between biocontrol - plant genetics

Both

Other (specify)*

No response

Single pest target

Multiple pest target

Both

Other (specify)*

No response

Strengthening the effectiveness of biocontrol by partial resistance Strengthening the effectiveness of biocontrol by other agronomic practices/DSS/strategies

Other (specify)*

No response

*Other responses which were different than those reported in the questionnaire are listed in Supplementary material S1 
Table 2. A final list of the most important common targets for new biocontrol products identified in arable crops across European countries. This list was sorted and ranked based on the two-day discussion of the biocontrol workshop. Arable crop group focused biocontrol solutions in sensu strictu which means that other alternative control options which form part of IPM (semiochemicals, fatty acids, botanicals, cultural practices, traps etc.) were not explicitly listed. In total, 13 priority pests were identified which were ranked into 3 classes: 1 = top priority, $2=$ medium priority \& $3=$ low priority.

Pest (s)

\section{Crop (s) Control solution under} development

$\begin{array}{ll}\begin{array}{l}\text { Potato, } \\ \text { maize }\end{array} & \text { Entomopathogenic fungi } \\ \text { Wheat } & \text { Trichoderma spp., Bacillus spp. } \\ & \begin{array}{l}\text { Antagonist bacteria and fungi for ear } \\ \text { treatment during flowering, crop }\end{array} \\ \text { Cereals, } & \begin{array}{l}\text { residues , mycotoxin detoxification } \\ \text { (e.g. degradation of deoxynivalenol), } \\ \text { maize } \\ \text { compounds produced by } \\ \text { microorganisms }\end{array}\end{array}$

Late blight

Soil-borne pests (e.g., Macrophomina , sp. Verticillium sp., Rhizoctonia sp., Plasmodiopora sp., Aphanomyces sp., Dickeya sp. and Pectobacterium sp,

Gaeumanomyces graminis)

Echinocloa sp., Alopecurus sp., Apera sp. potato

Pseudomonas spp. and Bacillus spp. antagonists, botanicals (Primula veris)

No

Polyversum

(Pythium

oligandrum),

Trichoderma spp.

Streptomyces spp.

Arable crops No

Pseudomonas spp. and Bacillus spp. antagonists, and many more

No

\section{Available for use Type of research needed}

Pest biology, screening of additional biocontrol solutions, proof of concept

Laminarine (brown Screening for other solutions

Polyversum

(Pythium

oligandrum
Conditions of effectiveness under field condition, improving application strategies (for Polyversum), additional biocontrol solutions, proof of concept of microbial crop residues \& seed treatments, endophytes

Screening for other solutions, improvement of existing candidates and formulation

Improved application technology, supporting soil suppressiveness

Screening of biocontrol agents (pathogens) and conservation biological strategies 
Cirsium sp.

Between $2 \& 3$

Between $2 \& 3$

Between $2 \& 3$

Sclerotinia rot

Seed-borne diseases (e.g.,

fusarium, Tilletia sp.)

Post-harvest pests (e.g., lepidoptera, coleoptera)
Rusts (Puccinia striiformis, Phoma Arable crops spp., Sclerotinia spp.), bacteria, flower-mining insects (Beauveria)

Oilseed rape Parasitoids

Oilseed rape Entomopathogenic nematodes

Oilseed rape,

sunflower Trichoderma spp., Verticillum spp soybean Bacillus sp.

Cereals Yes

Cereals
Available in NZ

(Phoma-based) but not in Europe

No

No

No

Contans, Bacillus

pumilus, Pythium

oligandrum

Mycostop

(Streptomyces sp.)

Cedemon and Cerall

(Pseudomonas sp.)

Trichogramma sp.,

other wasps,

predatory mites
Combine biocontrol agents with cultural practices (IPM)

Screening \& optimization of biocontrol agents

Screening \& development of

biocontrol agents, conservation biocontrol

Screening \& development of

biocontrol agents

Curative treatments, long term IPM strategies

Shelf-life of microbials on seeds

(development of expertise for seed production and treatments)

no research need identified 
Table 3. A final list of the most important common targets for new biocontrol products identified in vegetable crops (both indoor and outdoor) across European countries. This list was sorted and ranked based on the two-day discussion of the biocontrol workshop. The discussion was mainly focused on field vegetables. Biocontrol solutions were considered in sensu latu taking into account also other alternative control options which are part of IPM such as semiochemicals, fatty acids, botanicals, cultural practices, traps etc. In total, 12 priority pests were identified which were ranked from 1 to 12 in decreasing order of importance.

\begin{tabular}{llllll}
\hline Rank & Pest & Crop(s) & Control solution under development & Available for use & Type of research needed \\
\hline 1 & Weeds & all & rust, seed eating beetles, Alternaria spp. & research only & screening \\
2 & Root flies & $\begin{array}{l}\text { Brassicas, Onions, } \\
\text { Raddish, Carrots, Beans, }\end{array}$ & $\begin{array}{l}\text { Substrate management, PBMB, attract and kill, } \\
\text { conservative biocontrol, beneficials including } \\
\text { nematodes and entomopathogenic fungi }\end{array}$ & $\begin{array}{l}\text { nematodes, rove beetles, } \\
\text { predatory mites, fungi, } \\
\text { plant extracts }\end{array}$ & $\begin{array}{l}\text { engineering, and screening } \\
\text { for finding new solutions, } \\
\text { implementation }\end{array}$
\end{tabular}

3 Powdery mildew Tomatoes, Carrots, Cucurbits, Cabbage

Thrips

Aphids

White flies

Downy mildew
Brassicas, Onions, Leek, Tomatoes, eggplant, pepper

Leafy vegetables, Brassicas, Cucurbits, pepper, Solonaceae

Tomatoes and other solanaceous vegetables, Brassicas, Cucurbits, Lettuce, Onions, Leafy vegetables, Cucurbits, herbs
Green pesticides, induced Resistance, elicitor, yes plant resistance, antagonists,

Green pesticides, PBMB, beneficials, cons. Biocontrol, endophytes, plant resistance

\section{yes}

Conservative biocontrol, entomopathogens, green pesticides, beneficials

Beneficials, green pesticides,, PBMB, conventional biocontrol,

yes for finding new solutions, implementation

engineering, and screening for finding new solutions, implementation

screening, engineering

engineering, implementation, adoption

screening, engineering screening, engineering 
8 Fusarium sp. Onions, pepper, garlic,

11 Botrytis sp.

12 Oomycetes (Phythium, Phytopthora) cucurbits, asparagus

Carrots, tomatoes, eggplant, pepper, onions, lettuce melons

Brassicas, Tomatoes, pepper, Leafy vegetables,

Green pesticides, beneficials, conservation beans

Rootstocks, bio-fumigation, antagonists, endophytes, soil amendments, composts

biocontrol agents, green pesticides, trap plants

Leaf vegetables, Onions,

Beans, Tomatoes

Biocontrol, Trichoderma spp., green pesticides,

induced resistance, elicitor

Solanaceae, Carrots, lamb lettuce fumigation, soil amendment, forecasting induced resistance, antagonists yes

yes

screening, engineering

engineering, screening, implementation

engineering, implementation, adoption

screening and engineering for field, engineering for protected

screening, engineering 西

PBMB: Pest behavior manipulation for biocontrol including sexual pheromones, repellents/attractants, visual or odor confusion for plant location or mating, lures, etc. All products and techniques that can contribute to Biocontrol and have no direct lethal effects as insecticides or acaricides 
Table 4. A final list of the most important common targets for new biocontrol products identified in perennial crops (fruit crops and grapevines) across European countries. This was sorted and ranked from the initial list of 76 pest groups identified during the two-day discussion of the biocontrol workshop. Biocontrol solutions were considered in sensu latu taking into account also other alternative control options which are part of IPM such as semiochemicals, fatty acids, botanicals, cultural practices, traps etc. In total, 12 priority pests were identified which were ranked from 1 to 12 in decreasing order of importance. A: screening of new biocontrol agents; B: engineering of biocontrol products; C: Integration of biocontrol agents into IPM strategies, and D: Adoption of biocontrol: bottlenecks and levers at the farm and supply chain levels.

\begin{tabular}{|c|c|c|c|c|}
\hline Rank & Pest & Crop(s) & $\begin{array}{l}\text { Biocontrol solution } \\
\text { under } \\
\text { development }\end{array}$ & Available for use \\
\hline 1 & Drosophila suzukii & $\begin{array}{l}\text { all stone \& soft } \\
\text { fruits, grapes }\end{array}$ & None & None \\
\hline 2 & $\begin{array}{l}\text { Monilinia sp. (laxa, } \\
\text { fructicola, fructigena) }\end{array}$ & $\begin{array}{l}\text { all stone \& soft } \\
\text { fruit }\end{array}$ & None & None \\
\hline 3 & Venturia inaequalis & apple & None & None \\
\hline 4 & Cydia pomonella & $\begin{array}{l}\text { apple, pear, } \\
\text { walnut }\end{array}$ & $\begin{array}{l}\text { Trichogramma } \\
\text { (National project in } \\
\text { FR) }\end{array}$ & $\begin{array}{l}\text { Mating disruption; Granulosis } \\
\text { virus; Steinernema carpocapse; } \\
\text { sterile insect technique } \\
\text { (Canada) }\end{array}$ \\
\hline 5 & Psylla complex & apple \& pear & $\begin{array}{l}\text { Kaolin; not widely } \\
\text { used }\end{array}$ & $\begin{array}{l}\text { conservation biocontrol for } \\
\text { Psylla pyri }\end{array}$ \\
\hline 6 & $\begin{array}{l}\text { Rhagoletis cerasi + } \\
\text { fruit flies }\end{array}$ & $\begin{array}{l}\text { peach, cherry, } \\
\text { walnut, apple, } \\
\text { citrus, olive }\end{array}$ & None & None \\
\hline 7 & $\begin{array}{l}\text { Phytophthora } \\
\text { complex }\end{array}$ & $\begin{array}{l}\text { strawberry, cane } \\
\text { fruit }\end{array}$ & None & None \\
\hline
\end{tabular}

\section{Type of research needed}

biology of the pest; mass trapping; avoidance; parasitoids, repellants, pathogens, sterile insect technology

$\mathrm{A}$; then B; C would then priority (sanitation would be key - forecast models for timing of application), then $D$

A for overwintering inoculum; then B; C would then priority ( $\mathrm{R}$ varieties, forecast models for timing of application; technology for spraying without tractor), then D

A (e.g. new virus strains), B, C \& D (sterile insect technology, physical methods, landscape management \& conservation biocontrol

A (against vector \& endophytes against the phytoplasma); C (repellents / attractants, conservation biocontrol \& landscape management)

A (eg for attract \& infect/kill; attractants); C \& D (SIT, multispecies traps; IP with existing parasitoids, Beauveria, physical protection)

A then B; C (biofumigation + "cleaning crops"; detection method for sanitation soil/cuttings) 
$8 \quad$ Verticillium complex

$9 \quad$ Powdery mildews

Scaphoideus titanus

10 (Grapevine

Flavescence Dorée)

11 Plasmopara viticola

grapes

all stone fruit,

apple, grapes
None

None

None

None
A then B; C (biofumigation + "cleaning crops"; detection method for sanitation soil/cuttings)

A, B (improve existing BCAs), C

A (against the vector and gdf eg endophytes), C (combine BCAs with physical methods-vibration, mating disruption, repellants, avoidance techniques, trapping

A, B, C, D (test with predictive models)

pest biology; A (parasitoids); C (mass trapping, repellents/attractants), 